www.globaljournalseries.com, Email: info@globaljournalseries.com

\title{
U-Pb GEOCHRONOLOGY OF METASEDIMENTARY SCHISTS IN AKWANGA AREA OF NORTH CENTRAL NIGERIA AND ITS IMPLICATIONS FOR THE EVOLUTION OF THE NIGERIAN BASEMENT COMPLEX
}

BARTH N. EKWUEME AND FEIKO KALSBEEK

(Received 25 June 2012; Revision Accepted 5 November 2013)

\begin{abstract}
The geology of Akwnaga area of northcentral Nigeria is dominated by schists, metaigneous gneisses and weakly to nonfoliated granites. The Schist shows grades up to the sillimanite zone of the Barrovian type regional metamorphism and occurs as xenoliths in other rocks of the area. The zircons separated from a sample of the Schists show growth zoning and a number of grains display distinct cores and rims. Out of 131 analyses 117 yielded useful geochronological data. 67 of these gave $90-110 \%$ concordant results. Most ages scatter between 600 and $1100 \mathrm{Ma}$ with distinct peaks at 700,850 and 1000Ma. A few Archaean Zircons are also present but a minority of grains yielded Palaeoproterozoic ages (17002200Ma). These first-ever geochronological data from rocks of Akwanga area are further evidence of the polycyclic nature of the Nigerian basement. They confirm that the Pan-African orogeny, though pervasive, did not obliterate traces of earlier events in the Akwanga area.
\end{abstract}

KEYWORDS: Akwanga, Zircon, Archaean, Palaeoproterozoic, Polycyclic.

\section{INTRODUCTION}

McCurry (1976) recognized two classes of metamorphic rocks of sedimentary origin in the Nigerian Basement complex: the "Older Metasediments" was used to describe metasedimentary rocks deposited some $2,500 \mathrm{Ma}$ ago surviving in gneisses and migmatites. Oyawoye(1964) and Rahaman (1976) referred to these rocks as older metasedimentary series or the gneissmigmatite-quartzite complex. "Younger metasedimantary belts" were considered to have been deposited some $1000-800 \mathrm{Ma}$ ago. This group of rocks is also referred to as the Newer metasedimentary series and comprise pelites and semi-pelites that have been metamorphosed to form migmatized to non-migmatized paraschists in the Basement Complex of Nigeria (Oyawoye 1972; Rahaman 1976; Ajibade 1979). It was earlier thought that the Newer Metasediments occupy N-S trending belts (schist belt), that they are isoclinally infolded into the older metasediments and that they are restricted to the western half of Nigeria. Extensive geologic mapping and detailed geochronological studies have shown that both the Older and Newer Metasediments occur in every part of Nigeria (Ekwueme and Onyeagocha 1985; Ekwueme and Kroner 1997; Kroner et al. 2001).

In this contribution, metasedimentary rocks in the Akwanga area of northcentral Nigeria have been isotopically studied with a view to determining their ages and their implication for the tectonothermd evolution of the Nigerian Basement Complex.

\section{BRIEF DESCRIPTION OF METASEDIMENTS}

Onyeagocha $(1979,1984)$ and Onyeagocha and Ekwueme (1982) carried out a pioneer geological mapping of Akwanga area of norhcentral Nigeria. These authors mapped the northwest quadrant of the Nigerian topographic sheet 209 (Akwanga NW) in detail. The area lies between longitudes $8^{\circ} 00^{\prime} \mathrm{E}$ and $8^{\mathrm{O}} 15^{\prime} \mathrm{E}$ and latitudes $8^{\circ} 45^{\prime} \mathrm{N}$ and $9^{\circ} 00^{\prime} \mathrm{N}$ and belongs to the Nigerian Basement complex.

The rocks in the area include Schists which are the metasediments, augen gneiss and granite gneiss which are thought to be metaigneous. They were intruded by granites, pegmatites and dolerites (Fig. 1.)

The metasediments in Akwanga area are schists and these were described by Onyeagocha (1984) as River Andu schists and gneisses, migmatites, metaquartzites and ultramafic schists (Fig.1). Ekwueme (1978) mapped and studied in detail the schists in Kokona area which is the southwest part of northwest Akwanga area. This schist has been dated in this study. According to Ekwueme (1978) about one-third of Kokona area is underlain by schists. The largest outcrops occur in the valley of the tributary of River Andu which drains the area. Schists also occur as inclusions in other rocks in the area e.g. in Sabon

Barth N. Ekwueme, Department of Geology, University of Calabar, P. O. 3651, Calabar, Nigeria.

Feiko Kalsbeek, Geological Survey of Denmark and Greenland (GEUS). Øster Voldgrad 10, DK- 1350 Copenhagen K. Denmark. 
Gida Augen Gneiss in which case it is unmappable. In the stream channel and south of Sabon Gida, a massive fresh outcrop of schists occurs. The schists is fine-grained in texture and dark in colour. The schistosity strikes northeast. This schist extends to Tudun Wada in the central part of Kokona area. Here, It is medium grained and thinly banded (1-2mm wide). The light band is composed of feldspar and quartz whilst the dark band shows parallel alignment of biotite. The layers are possibly indicative of the sedimentary origin of the schists.

As noted by Onyeagocha (1984) the River Andu schist is in many locations e.g. west of Garaku to Angwan Mayo (Fig. 1) intermingled with migmatite and migmatitic gneiss. They are also associated with pegmatitic veins and dykes and in one location at Angwan Mayo the schist with $\mathrm{E}-\mathrm{W}$ foliation trend has been transected by migmatite trending N-S. Onyeagocha and Ekwueme (1982) pointed out that such offset of foliation trends depicts that at least two deformation episodes affected the rocks in the Akwanga area and that the E-W trend represents the earlier pre-Pan African deformation whilst the N-S trend is due to the Pan-African tectonothermal event (cf. Grant 1978; Mullan 1979).

Petrography: Ekwueme (1978) identified three categories of schists on basis of petrography in the Kokona area: Mica schist, Hornblende-biotite schist and Garnetiferous mica schist. The modal composition of these schists are shown in Table 1. The mica schist is medium-grained and prismatic tourmaline crystals up to $5 \mathrm{~mm}$ long occur in some samples. Plagioclase composition is An26-32 and the crystals are polysynthetically twinned. A sample from Gudindi contains staurolite (up to 10\%). The presence of staurolite indicates that the protolith of the schist was possibly pelitic in composition. The Hornblede biotite schist is coarse grained. The anorthite content of plagioclase in this schist is An26-33. Some portions of this schist is banded.

On the basis of the petrography of the River Andu schist, Onyeagocha (1984) assigned the Akwanga area to the Barrovian type of regional metamorphism. The occurrence of kyanite and silimanite in some River Andu schist samples is an evidence of high-grade metamorphism. The plagioclase composition ranges from oligaclase to andesine and schists and gneisses in the area are associated with anatectic migmatites and granites indicative of temperature high enough to initiate partial melting. Onyeagocha and Ekwueme (1990) estimated the temperature in Akwanga area to have reached $600-750^{\circ} \mathrm{C}$ whilst their estimate for pressure is 5$8 \mathrm{kbar}$

\section{GEOCHEMISTRY}

Kalsbeek et al. (2012) analyzed a representative sample of the schist in Kokona area and the chemical composition is shown in Table 2. A plot of the chemical data on the $\mathrm{Na}_{2} \mathrm{O} / \mathrm{Al}_{2} \mathrm{O}_{3}$ against $\mathrm{K}_{2} \mathrm{O} / \mathrm{Al}_{2} \mathrm{O}_{3}$ diagram of Garrels and Mackenzie (1971) used to discriminate between metaigneous and metasedimentary rocks shows that the protolith of the schist was sedimentary. $\mathrm{Na}_{2} \mathrm{O}$ is however higher than $\mathrm{K}_{2} \mathrm{O}$ in the rock indicating that it is a greywacke or semi-pelitic. The composition approximates that of an average greywacke reported in Pettijohn (1975). Infact, the schist plots in the field of Francican greywacke of Brown et al. (1979) in the $\mathrm{SiO}_{2}$ vs $\mathrm{CaO}$ diagram. And in the ACF diagram of Winkler (1967) the Akwanga schist plots in the field of greywacke. The Niggli norm of the schist was calculated and it shows positive quarrzal ( $q=$ +138 ) and upto $38 \%$ Niggli al. A plot of Niggli al - alk vs. Niggli $C$ shows that the rock falls outside the igneous envelop confirming that the parent rock was sedimentary.

Kalsbeek et al. (2012) also obtained $\mathrm{Rb}-\mathrm{Sr}$ and $\mathrm{Sm}-\mathrm{Nd}$ data for the Akwanga schist (Table 4). The Th/U value of the schist is also shown in Table 4. The Initial ${ }^{87} \mathrm{Sr} /{ }^{86} \mathrm{Sr}$ ratio of 0.71879 indicates that the schist is a product of tectonothemal reworking of crustal sediments at about $600 \mathrm{Ma}$ ago. The Th/u ratio is 0.61 whilst the $\mathrm{Tdm}$ is 1.46. it has an End (600) value of -1.12 , suggesting it contains mainly Neoproterozic detrital material.

\section{GEOCHRONOLOGY}

The schist from Kokona analyzed in this study was collected from $08^{\circ} 01^{1} \mathrm{~N}$ and $08^{\circ} 48^{1} \mathrm{E}$ in the Akwanga area of northcentral Nigeria. Zircons for U-Pb geochronology were separated using standard techniques-crushing and sieving to $<300 \mu \mathrm{m}$, washing on a Holman-Wilfley shaking table followed by hand picking. Hand picked zircon grains were set in 1-inch expoxy mounts, sectioned and polished to approximately half their thickness. Back-scatter images of the zircons were obtained by Scanning Electron Microscopy (SEM) at the Geological Survey of Denmark and Greenland (GEUS) and analytical spots (diameter $25 \mu \mathrm{m}$ ) were selected with the help of the SEM images. Isotopic analysis was performed by laser ablation single collector magnetic sector field-inductively coupled plasmamass spectrometry (LA-ICP-MS) at GEUS, using a Thermo-Fischer Element 11 sector field ICP-MS coupled to a Newwave UP213nm Nd-YAG laser ablation unit. The methods applied essentially follow those of Gerdes and Zeh (2006), Frei et al. (2006) and Frei and Gerdes (2009).

The GJ-1 zircon (609Ma), Jackson et al. (2004) was used as primary standard. The chronological data were presented as ${ }^{267} \mathrm{~Pb} /{ }^{206} \mathrm{~Pb}$ age probability diagrams prepared with the help of the Age Display programme of Sircombe (2004). 


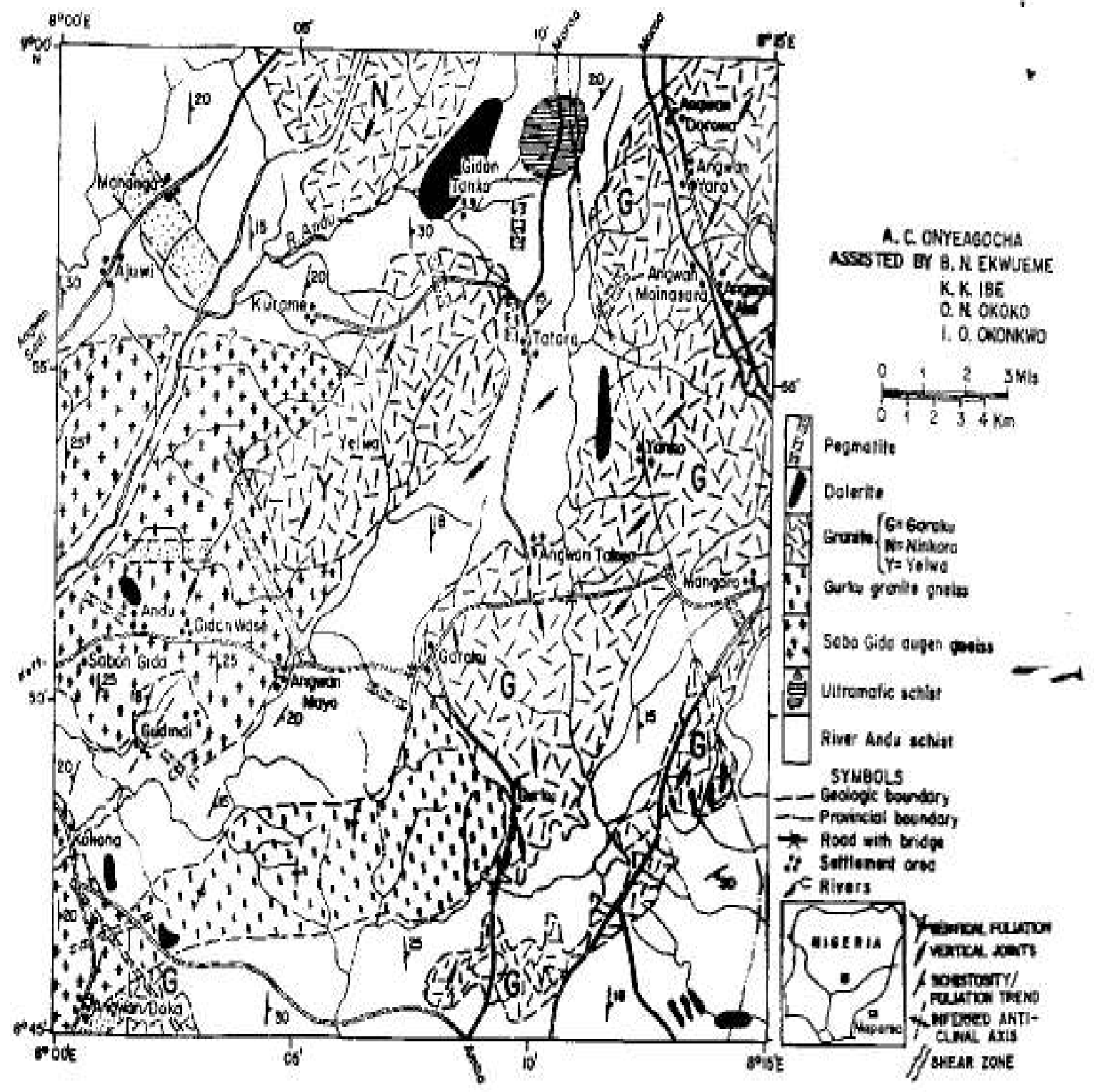

Fig̣. 1. Gcologic map of A kwąnga NW (Geological Surver of Nigeria sheet $209 \mathrm{NW}$ ).

(Atter Onyeugocha 1984) 


\section{RESULTS}

Zircons separated from the schist in Kokona area of northwest Akwanga are broadly subhedral, sometimes with preserved pyramidal faces. They are relatively small and subby, mainly 65-125 $\mu \mathrm{m}$ in length (mean length $95 \mu \mathrm{m}$ ) and with aspect ratios mainly 1.4-2.5 (mean 2.1). Many grains show growth zoning, and a number of grains display distinct cores and rims, too thin for analysis, and small irregular outgrowths are commonly present.

Out of 131 analyses 117 yielded useful geochronological data; 67 of these gave $90-110 \%$ concordant results. $U$ and Th concentrations vary widely, 60-3000ppm and 7-1350ppm respectively. Mean values for $U$, Th and Th/U are 485ppm, 263ppm and 0.61. Most ages scatter between 600 and $1100 \mathrm{Ma}$, with distinct peaks at 700, 850, and 1000Ma (Fig. 2). A minority of grains yielded Palaeoproterozoic ages (1700-2200Ma). A few Archaean zircons are also present. One zircon rim with an age of $669 \pm 46 \mathrm{Ma}$ had very low Th/U (0.01) and is considered to have formed during metamorphism. All other zircons in Kokona schist and the age distribution is similar to that of Oti Group of Volta Basin in Ghana (Kalsbeek et al. 2012) and Kwa Falls schist of southeastern Nigeria (Ekwueme et al. 1988). 


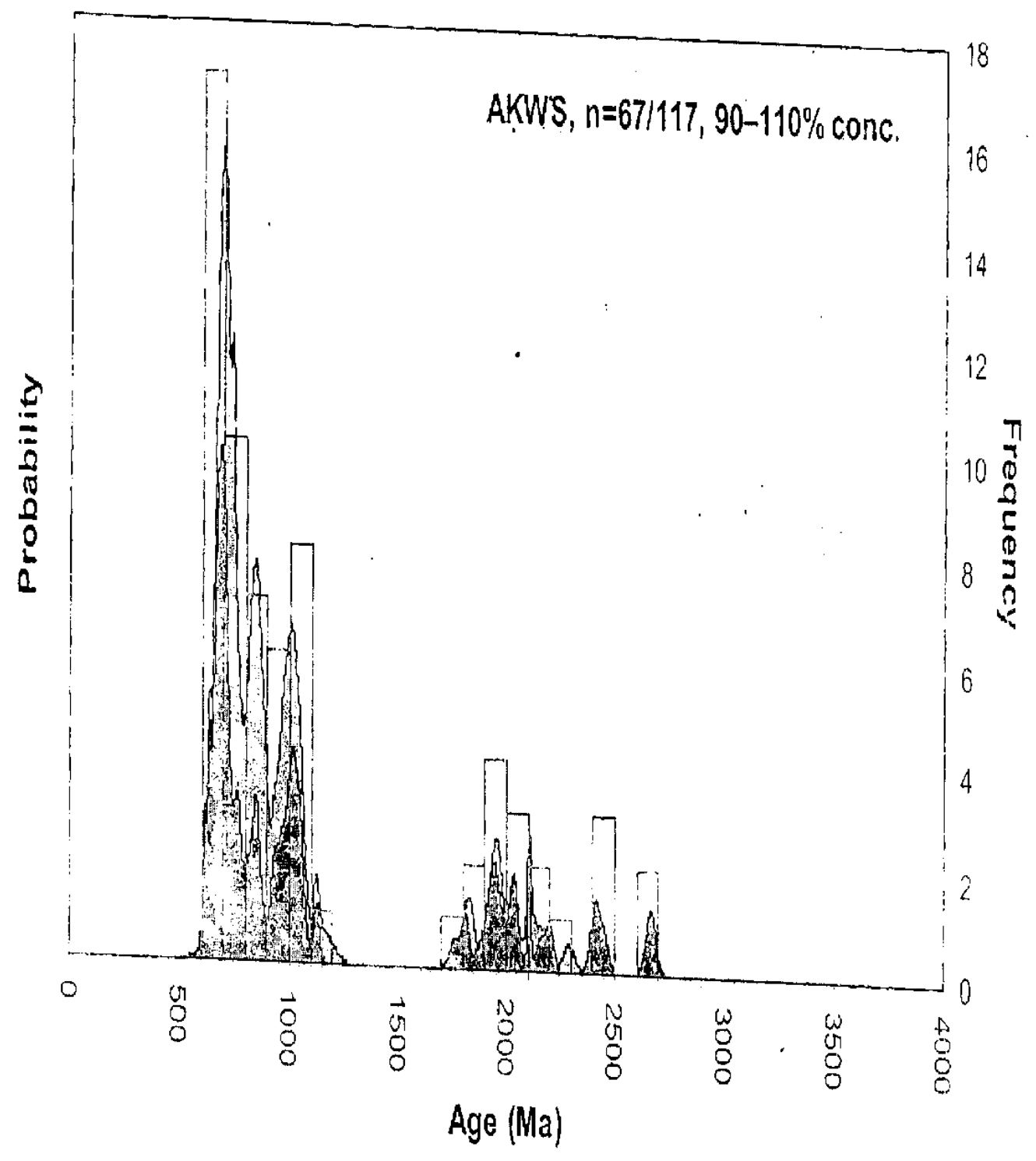

Fig. 2. $\quad{ }^{207} \mathrm{~Pb}{ }^{211 k} \mathrm{~Pb}$ zircon age probability diagram representing samples of schist in Akwanga area of Northcentral Nigeria. 


\section{DISCUSSION}

The polycyclic metamorphism and polyphase deformation that affected the Nigerian Basement complex have been adequately reported in petrological literature (Oyawoye 1972, Rahaman 1976, McCurry, 1976, Dada 1999; Onyeagocha 1984; Ajibade 1972; Kroner et al. 2001, Ekwueme and Kroner 2006 among others). These authors showed that in many parts of Nigeria rocks that have been affected by Liberian $(2800 \pm 200 \mathrm{Ma})$, Eburnean $(2000 \pm 200 \mathrm{Ma})$ and Pan-African $(600 \pm 150 \mathrm{Ma})$ occur and sometimes in one locality. Ekwueme (1989) for instance, discussed the tectonothermal events that affected rocks including schists in Uwet area, Oban massif southeastern Nigeria. He showed that the main phase of metamorphism that affected the rocks in the area was Pan-African dated at Ca.676Ma. Ekwueme (2004) showed that the Uwet schists are extension of Poli schists in northern Cameroon. Ekwueme and Kroner $(1997,2006)$ showed that similar schists occur in the Obudu Plateau which is a part of the Bamenda massif of Cameroon Republic and ages representing the Archaean, the Palaeoproterozoic and the Pan African events affected the Obudu schists in Bagga Utanga.

Pidgeon et al. (1976) had reported Archaean ages in rocks in lbadan area which are dominantly Pan-African in age. In a similar manner Annor (1983) had reported older ages occurring together within dominantly PanAfrican rocks in Egbe area of southwest Nigeria. The schists in northwest Nigeria have also shown ages of Archaean, Palaeoproterozoic and Pan African (Ajibade et al. 1979).

The identification of zircons of Archaean, Palaeoproterozoic and Pan-African ages in Kokona area of northwest Akwanga in northcentral Nigeria which is the result of the first-ever isotopic dating of rocks for this part of the Nigerian basement is a further evidence of the polycyclic nature of the entire Basement Complex of Nigeria. It confirms the assertion that Pan-African event that affected rocks in many parts of Nigeria did not obliterate traces of earlier events (Mullan 1979, Grant 1978, Ekwueme 1987; Onyeagocha and Ekwueme 1982). In the Mayo Dayo area of northwest Akwanga the truncation of the pervasive Pan-African foliation trend ( $\mathrm{N}$ S) by an E-W trending one (Onyeagocha 1984) is an elegant evidence that pre-Pan African ages and pre-Pan African structural features occur in the Nigerian Basement complex and this demonstrates the polyphase nature of the deformation.

\section{CONCLUSION}

Schists belonging to the older metasedimentary series of McCurry (1976) occur in Akwanga area of northcentral Nigeria. These schists which were metamorphosed up to the uppermost amphibolite facies of the Barrovian type yielded dominantly Neoproterozoic age of 669Ma but contain detrital zircons showing relict ages of Archaean and Palaeoproterozic. These ages are a further evidence of the polycyclic and plyphase nature of the Nigerian Basement complex.

\section{DEDICATION}

This paper is dedicated to the cherished memory of Prof. Anthony Chukwuma Onyeagocha who died $28^{\text {th }}$ August 1987. He was the first geologist to carry out a detailed geological mapping of northwest Akwanga area of northcentral Nigeria in 1978-1979.

\section{ACKNOWLEDGEMENTS}

The part played by Bassey, I. Essien in the location and collection of samples used in this study is appreciated. The authors are grateful to the Geological Survey of Denmark and Greenland (GEU) for allowing the use of its facilities for the isotopic and chemical analyses of these schists. 
Table 1: Modal Composition of schists in Kokona area NW Akwanga

\begin{tabular}{|llllll|}
\hline SAMPLE: & 1 & 2 & 3 & 4 & 5 \\
\hline Plagioclase & 10 & 5 & 10 & 15 & 15 \\
Biotite & 35 & 45 & 35 & 35 & 30 \\
Muscovite & 20 & 20 & 20 & - & - \\
Hornblende & - & - & - & 25 & 23 \\
Quartz & 30 & 30 & 30 & 25 & 25 \\
Granet & 2 & - & 2 & - & - \\
Tourmaline & 2 & - & 1 & - & 2 \\
\hline
\end{tabular}

Table 2: Major Element Composition of Analyzed Sample

\begin{tabular}{|l|l|}
\hline $\mathrm{SiO}_{2}$ & 68.20 \\
\hline $\mathrm{TiO}_{2}$ & 0.73 \\
\hline $\mathrm{Al}_{2} \mathrm{O}_{3}$ & 14.20 \\
\hline $\mathrm{Fe}_{2} \mathrm{O}_{3}$ Total & 5.65 \\
\hline $\mathrm{MnO}$ & 0.09 \\
\hline $\mathrm{MgO}$ & 2.23 \\
\hline $\mathrm{CaO}$ & 1.59 \\
\hline $\mathrm{Na}_{2} \mathrm{O}$ & 2.91 \\
\hline $\mathrm{K}_{2} \mathrm{O}$ & 2.62 \\
\hline $\mathrm{P}_{2} \mathrm{O}_{5}$ & 0.16 \\
\hline Volatile & 1.07 \\
\hline Sum & 99.47 \\
\hline A/CNK & 1.35 \\
\hline
\end{tabular}

Table 3: Trace Element Composition of Analyzed Sample

\begin{tabular}{|l|l|l|l|}
\hline $\mathrm{CS}(\mathrm{PPM})$ & 5.5 & $\mathrm{La}(\mathrm{PPM})$ & 25.93 \\
\hline $\mathrm{Rb}$ & 94 & $\mathrm{Ce}$ & 53.13 \\
\hline $\mathrm{Ba}$ & 522 & $\mathrm{Pr}$ & 7.11 \\
\hline $\mathrm{Pb}$ & 16 & $\mathrm{Nd}$ & 26.60 \\
\hline $\mathrm{Sr}$ & 214 & $\mathrm{Sm}$ & 5.78 \\
\hline $\mathrm{Y}$ & 32 & $\mathrm{Eu}$ & 1.26 \\
\hline $\mathrm{Th}$ & 7.5 & $\mathrm{Gd}$ & 5.12 \\
\hline $\mathrm{Cu}$ & 1.9 & $\mathrm{~Tb}$ & 0.84 \\
\hline $\mathrm{Zr}$ & 185 & $\mathrm{Dy}$ & 4.96 \\
\hline $\mathrm{Hf}$ & 4.7 & $\mathrm{Ho}$ & 1.12 \\
\hline $\mathrm{Nb}$ & 11 & $\mathrm{Er}$ & 2.89 \\
\hline $\mathrm{Ta}$ & 1.2 & $\mathrm{Tm}$ & 0.48 \\
\hline $\mathrm{Zn}$ & 70 & $\mathrm{Yb}$ & 3.04 \\
\hline $\mathrm{Cu}$ & 6.7 & $\mathrm{Lu}$ & 0.47 \\
\hline $\mathrm{Ni}$ & 42 & & \\
\hline $\mathrm{Sc}$ & 13 & & \\
\hline $\mathrm{V}$ & 94 & & \\
\hline $\mathrm{Cr}$ & 86 & & \\
\hline $\mathrm{Co}$ & 19 & & \\
\hline $\mathrm{Ga}$ & 17 & & \\
\hline
\end{tabular}




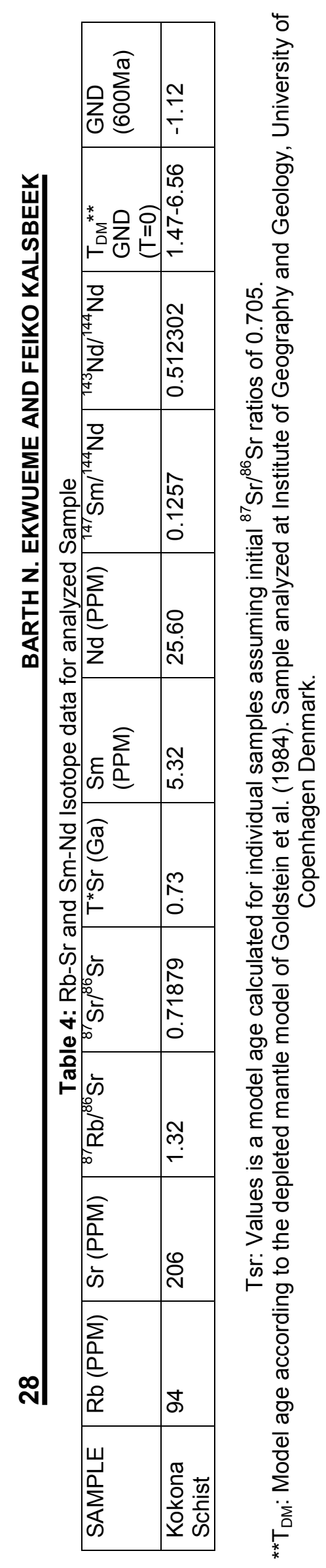




\section{REFERENCES}

Ajibade, A. C., 1976. Rrevisional classification and correlation of the schist belts of northwestern Nigeria. In: Kogbe, C. A. (ed.) Geology of Nigeria. Elizabethan Publ. Co., Lagos, P. 85-90.

Ajibade, A. C., 1982. Origin and emplacement of the Older Granites of Nigeria: some evidence from Zungeru region. Nigeria J. Min. Geol. 19, (1): 221-230.

Annor, A. E., 1983. Metamorphism of pelitic schists in relation to deformation episodes around Okene, Nigeria. Nigerian J. Min. Geol. 20, (1\&2): 17-24.

Brown, E. H., Babcock, R. S., Clark, M. D and Livingstone, D. E., 1979. Geology of the older Precambrian rocks of the Grand Canyon, Part 11: Petrology and structure of the Vishnu complex. Precamb. Res. 8, 219-241

Dada, S. S., 1999. Geochemistry and petrogenesis of the reworked Archaean gneissic complex of Northcentral Nigeria: major and trace element studies on Kaduna emphibolites and migmatitic gneisses. Global J. Pure \& Appli. Sci., 5, 535-543.

Ekwueme, B. N., 1978. Geology of Kokona and its environs Keffi Local Government, Plateau State, Nigeria. Unpubl. B. S. Thesis, Univ. of Nigeria, Nsukka.

Ekwueme, B. N., 1987. Structural orientations and Precambrian deformational episodes of Uwet area, Oban massif, southeastern Nigeria. Precamb. Res. 34, 269-289.

Ekwueme, B. N., 1989. Tectonothermal evolution of Oban massif, Nigeria. Proceed. $28^{\text {th }}$ Int. Geol. Congr. Washington D. C., Abstract 1, 439-440.

Ekwueme, B. N., 2004. The Pan-Africa schist of southeastern Nigeria and their relationship with schists of NW Cameroon. IGCP 470 Field conference, Garoua Cameroon. Abstract volume.

Ekwueme, B. N and Kroner, A., 1997. Zircon evaporation ages and chemical composition of a migmatitic schist in Obudu Plateau evidence for Palaeoproterozoic ca. 1789Ma component in the basement complex of southeastern Nigeria. J. Min. Geol. 33, (2): 81-88.

Ekwueme, B. N and Kroner, A., 2006. Single zircon ages of migmatitic gneiss and granulites in the Obudu Plateau: Timing of granulite facies metamorphism in southeastern Nigeria. J. Afr. Earth Sci., 44, 459469.

Ekwueme, B. N and Onyeagocha, A. C., 1985. Metamorphic Isograds of Uwet area, southeastern Nigeria. J. Afr. Earth Sci, 3, (4): 443-454.
Ekwueme, B. N., Caen-Vachette, $M$ and Onyeagocha, A. C., 1988. Rb-Sr geochronology of metasedimentary schists and gneisses in Uwet area, Oban massif, southeastern Nigeria. Nigeria J. Min. Geol. 23, 119-124.

Fitches, W. R., Ajibade, A. C., Egbuniwe, I. G., Holt, R. W and Wright, J. B., 1985. Late Proterozoic schist belts and plutonism in NW Nigearia. J. geol. Soc. London 142, 319-337.

Frei, D and Gerdes, A., 2009. Accurate and precise U-Pb zircon dating with high sample through put by automated LA-SF-ICP-MS. Chemical Geology 261, 261-270.

Frei, D., Hollis, J. A., Gerdes, A., Harlov, D., Karisson, D., Vasques, P., Franz, C., Johansson, L and Knudsen, C., 2006. Advanced in-situ trace element and geochronological microanalysis of geomaterials by laser ablation techniques. Geol. Surv. Denmark and Greenland Surv. Bull. 10, 25-28.

Gerdes, A and Zeh, A., 2006. Combined U-Pb and Hf isotope LA-(MC)_ICP_MS analyses of detrital zircons: comparison with SHRIMP and new constraints for the provenance and age of an Amorican metasediment in central Germany. Earth and Planet Sci. Lett. 249, 47-61.

Grant, N. K., 1978. Structural distinction between a metasedimentary cover and underlying basement in 600M.Y. old Pan African domain of northwestern Nigeria, West Africa. Geol. Surv. Am. Bull. 89, 50-58.

Jackson, S. E., Pearson, N. J., Griffin, W. L and Belousova, E. A., 2004. The application of laser ablationinductively coupled plasma-mass spectrometry to in situ $\mathrm{U}$ - $\mathrm{Pb}$ zircon geochronology. Chemical Geology 211, 47-69.

Kalsbeek, F., Affaton, P., Ekwueme, B. N., Frei, R and Thrane, K., 2012. Geochronology of granitoid and metasedimentary rocks from Togo and Benin, West Africa: comparisons with NE. Brazil. Precamb. Res. 196-197, 218-233.

Kalsbeek, F., Ekwueme, B. N., Penaye, J., de Souza, Z. S and Thrane, K., 2013. Recognition of early and late Neoproterozoic supracrustal units in West Africa and North East Brazil from detrital zircon geochronology. Precamb. Res. 226, 105-115.

McCurry, P., 1976. The geology of the Precambrian to lower paleaozoic rocks of northern Nigeria. In C.A. Kogbe (Editor) geology of Nigeria, Elizabethan publ. Lagos, P.15-31.

Onyeagocha, A. C., 1979. Basement rocks of Akwanga, N.W. (sheet209). Plateau State (Abstract). D. Min Geol 16, 97. 
Onyeagocha, A. C., 1984. Petrology and geologic history of NW Akwanga area in northern Nigeria. J. Afr. Earth Sci. 2, 41-50.

Onyeagocha, A. C and Ekwueme, B. N., 1982. The prePan African structural features in northcentral Nigeria. J. Min. Geol. 19, 74-77.

Onyeagocha, A. C and Ekwueme, B. N., 1990. Temperature - pressure distribution patterns in metamorphosed rocks of the Nigerian basement complex - a preliminary analysis. J. Afri. Earth Sci. 11, 83-93.

Oyawoye, M. O., 1964. The geology of the Nigerian. Basement complex - A survey of our present knowledge of them. J. Nigerian Min. Geol. Metal. Soc. 1, 87-103.

Oyawoye, M. O., 1972. The basement complex of Nigeria. In Dessauvagie, J. F. J. and Whiteman, A. J. (Editor) African Geology, Geology Dept. Univ. Ibadan, P. 67-97.

Rahaman, M. A., 1976. Progressive PolyPhase metamorphism in politic schists around Aiyetoro, Oyo State, Nigeria. J. Min. Geol. 12, (2): 33-44.

Sircombe, K. N., 2004. Age display: an EXCEL workbook to evaluate and display invariate geochronological data using binned frequency histograms and probability density sistributions. Computers and Geosciences 30, 21-31.

Winkler, H. G. F., 1967. Petrogenesis of metamorphic rocks. $2^{\text {nd }}$ edition. Springer - Verlag, New York, 237. 